\title{
The Importance of Corporate Social Responsibility
}

\author{
Dr. Sanie DODA \\ Lecturer, Aleksander Moisiu University \\ Durres, Albania \\ E- mail: sanijedoda@yahoo.com
}

Doi:10.5296/ jsr.v6i1.7426 URL: http://dx.doi.org/10.5296/ jsr.v6i1.7426

\begin{abstract}
The history of the social responsibility of CSR corporation and their companies lays in over one hundred fifty years. The word "company" derives by the two Latin words "cum" and "pains", that mean "to share the food together".

Despite the negative sides and distortions, this term lately, is translated by the result of a widely usage as an instrument for the public relations (PR). CSR represents the idea of an ethical organization, that has social obligations and that can take responsibilities as the individuals can do.

The high rhythm of the technological advances,services and new products that change in a constantly way the needs and desires, the innovative ideas, the similarities and the business requests to exceed and the consumer's expectations.

All these factors that contribute for the crossing of a society oriented in goods into a society oriented in persons. The lack or the absence of realization and the sense of the cause, the weak role of society in relations take and give to the CSR's business and the legal frame in equation to support the increase of community's commitment are the factors which contribute in the concentration of the CSR on the business side.

In developed countries the business should take the direction and involve operations with social commitment and manners. Meanwhile the governments should behave like a "laissez faire"to encourage the civil orientation and the consumption interests groups.
\end{abstract}

Keywords: Corporate Social Responsibility business, markets, consumer. 


\section{Corporate Social Responsibility}

Corporate Social Responsibility is considered as an important instrument that pushes the competitive advantages, the creativity and innovation, improves the business reputation to the society with the employees, furniture, state institutions and nongovernmental organizations.

All the abovementioned are actions which take to an increase of value. (Accelerating CSR 2008) However, there are no final conclusions in this area and the CSR's effects on organizational values are still discovering. First of all this section highlights the CSR's effects on the financial performance and than it reviews the impact on competitive advantages and organizational values beyond the terminal lines. Nowdays, there are a few significant studies that explore the CSR's financial and economic influence (Gond 2001). Finding these link-ups was not an easy job. The gaps has come as a result of a vague social and economical definitions. Studies give mixed conclusions. Some of them show a positive relation and others show a little or no interaction.

Scholars as Waddock and Graves (1997) concluded on their analysis for the existence of a weak but significative connection between CSR and financial performance. Other later studies proved that some CSR's actions really affect positively on the financial performance, but not all of them. The effects depend on some institutional and national factors (Allaiche and Laroche 2005, Gond 2006a) or they depend on the market strengths such as request and offer for CSR in the market.

Despite of the studies that claimed this positive relation between CSR and its financial performance there were given evidences. How does it work. Some perspectives focus on the role of the interested pairs, mediator groups in the relation. The research's attention is shafted at consumer and employee's attitude and behavior, as the main group of the interested pairs (Wood and Jones 1995, Rowley and Berman 2000, Luo and Bhattacharya 2006, Schuler and Cording 2006). Husted and Allen (2001) developed a theoretical model on explaining the convergence of strategic implementation in a higher organisational performance. The authors concluded that: When CSR's strategy integrate in successful way with a general business strategy, it encourages the competitive advantages and increases the financial and social performance.

With the globalization's increase, the business value flow more by the untouchable and good wishes side than by the number's side. There are some limited studies for the organisational value is considered as a value beyond the final line in some foreign and internal dimensions.

These values by creating dimensions, involve all the general aspects such as: development and maintenance of human resources, the pleasure and loyalty of the client, the innovation and reputation of the brand. They can give positive impacts on financial performance, but they can also return in important resources of risk. The most part of studies till now, have mainly been focused on determination and group interested pairs and on the distribution as a subject and its relations with the CRS corporation's performance.

This section treats standards that different authors have used to measure the success of CSR's strategies despite of the difficulties it represents. As a general business rule, it is not so much 
important in which typology does the corporate focus. The important thing is to determine its success based on the valuation standards. (Porter and Krarmer 2006)

Schermerhorn (2004) designed the valuation standards of CSR based on 4 strategies and on the CSR pyramid. Depending on the type of the strategy that a company can chose to implement, the standards of Schermerhorn are:

\section{Profitability}

2. Legitimacy

3. Ethics

\section{Philantrophy}

The first two dimensions are those which Schermerhorn calls the area of correspondence. It means that the corporation should obey the law and the interested pairs.

The last two dimensions are part of the persuasion's area, because of the bigger commitment on CSR and on the progress of voluntary actions.

Schermerhorn's valuation standard like his strategically model are very specific and very close to the pyramid of Carroll (1979). When we talk about new organizational values by the strategy implement of CSR, Balgobin (2007), we refer the actions of De Beer in South Africa. Because of the spreading of HIV, the corporate faced a higher cost of medical treatment and at the same time with a higher cost of employee. De Beer soon recognized that the solution was in the social reaction. The company took some awareness campaigns for HIV at the community they were working. The campaigns were resultative for the fruitfulness improvement and consequently it kept down the widely community.

Based on the model of Husted and Allen (2001)of corporation's social strategy Detchev (2005) identified positive dimensions of CSR that was useful on the determination of CSR's added values in an organization. The author also identifies negative aspects of CSR, which were used as criticism of the CSR.

CSR is also a different instrument in the market. It's innovative and creative in a business world where innovation is considered one of the most competitive key instruments. All of these positive things take to a generally improved benefit based on the best talents, on faithful relations, competitive advantages, and on the trade of the programme and strategies' importance CSR (Wall 2008).

Zadek (2004) has developed a model with 5 phases that companies should pass when they take the responsibility of corporation. The author claims that the corporate move in life cycle toward maturity, as the society does. He calls this journey "the civil learning". In other words , it's the point where society becomes conscious for sensitive causes, recognizes these causes, educate itself about these causes and creates rules in which determines the position of a company and the acceptable practices.

Five dimensions of the standard that Burke and Logsdon (1969) have identified: 
1. Centrality: the goodness of adaptation between the CSR's strategy and the mission and targets of organization.

2. Specific : organizational skills to get integrated private benefits.

3. Proactive: The degree where are predicted social trends and program's compilation to precede them and to prevent crisis.

4. Volunteerism : The target for getting a special decision without the need of outdoor compliance request.

5. Visibility : It's obvious and it can be recognized by all the interested pairs of the organization

\section{The creation of value}

The low level of internationalization between all the companies in study, in any way justify the absence of a strong relation between CSR and markets. This is also one of the reasons why market's dimension should be considered as an implementation aspect of CSR's strategy more than a creation dimension's value. When it comes to market and capitals, it's important to say the fact that three companies hasn't been faced with causes like these and therefore they cannot give appropriately information. The crossed analysis shows that CSR can have some effects that now corporate choose markets to make their business.However CSR's impacts markets on determination are less comparing with its impacts over companies that are active in these kind of markets.As a conclusion it seems that there might have a big disagreement for the perception of the values creation at market's dimension.

Consumer: The three studied companies agree that CSR and consumer's purchases or their loyalty are nearly not connected with each other. Besides all of them has confronted difficulties on finding and identifying the group of the loyal custom. For this reason the crossing analysis shows that the creation of values in the market dimension is dark, with two meanings and even quite insignificant.

\section{Reputation / advertising:}

Generally, companies agree to some extent, between the correlation CSR practices and reputation of the company. The interesting fact is that CSR strategies or aspects have not been used in any advertising tool. Algorithm companies have other communication path to their social values. Examples canbe the annual reports, CSR reports, Web and intranet and internal tools most important marketing. Of the three companies, Birra Tirana is only on the quality of beer and pleasure.

One possible explanation that can be given for not using plausible explanation that can be given for not using CSR as a marketing tool is that it is not considered appropriate to do. Community and business world are recently abusing the term, making the term of losing the real significance.

Furthermore, the use of CSR as a marketing tool, can lead to increase not reach these expectations. However, the three companies come to a common term that CSR felt in 
necessary be used as a public relations tool and that proactive promoters are those that can take benefit. Media attention is occasionally helpful, as enabling companies to make their promotion of through several initiatives in terms of stakeholders.

The three companies are aware of the disadvantages that accompany implementation of CSR. Disadvantages of VDO company, as were discussed in the internal analysis, are consistent with the creation of negative values, Dentchev (2005).

The greatest obstacle EEC was evidenced by the three companies was high level and sometimes unrealistic expectations that put CSR. It is true that these high expectations in a civil way help companies become better. However, the atom can easily become a source of criticism every time there is any gap between promised standards and current conditions. At the same time, all companies participating are aware that not all standard can be accessed.

\section{Conclusions and recommendations:}

Theories suggest that Corporate Social Responsibility strategies can develop sustainable competitive advantages, to enhance social and financial performance and therefore increase organizational performance beyond numbers and bottom lines.

Results suggest that CSR oriented organizational values reinforces CSR strategies of each company which in turn brings added value strengthening beyond bottom line or beyond finance.

Added values become more prominent in internal dimensions such as human resources and operations, and the external dimension such as reputation and external interest groups. However, added values depend on the prospects CSR that companies choose to follow and implement.

This study attempted to investigate whether companies in the Albanian market can be successful by having a social orientation which consists in doing good for society. Results suggest EEC CSR contributes to increasing value for the company. However, the way how they expect these values depend on CSR perspective they adopt, the awareness about possible pitfalls and establishing the foundation of CSR in business as well.

The results of this study could be used more in company studied with a CSR strategy against those companies that have not published it clearly. Also it would be interesting to include the more national or international companies, or global scope operating in other developing countries to see whether the results of this study are consistent with all countries or industries.

Further studies in the field of CSR could have been in accordance with the results of this paper regarding the components of CSR, implementation, value creation and experience of these values.

\section{Bibliography}

Acceleratingcsr, 2008. Corporate Social Responsibility: An Implementation Guide for Business. Available from:

Allouche, J., and Laroche, P., 2005. A meta-analytical examination of the link between 
corporate social and financial performance. Revue Française de Gestion des Ressources Humaines, 57, 18-41.

Balgobin, R., 2007. CSR and the Triple Bottom Line. Available from: http://www.gsb.tt/articles/uploads/08_csr_and_the_triple_bottom_line_pt1.pdf [Accessed 19 August 2008]

Burke, L. \& Logsdon, J. 1996. How Corporate Social Responsibility Pays Off. Long Range Planning, 29 495-502

Carroll, A., 1979. A Three-Dimensional Conceptual Model of Corporate Social Performance, Academy of Management Review 4 (4) 497-505

Dentchev, N. A. 2004. Corporate Social Performance as a Business Strategy. Journal of Business Ethics, 55(4): 395-410

Gond, J. P., 2001. L'éthique est-elle profitable?. Revue Française de Gestion, 136, November - December, 77-85.

Griffin, J. J, and Mahon, J. F., 1997. The Corporate Social Performance and Corporate Financial Performance Debate. Business and Society, 36(1): 5-31

http://www.acceleratingcsr.eu/uploads/databases/files/2007_IISD_CSR_Implementation_Gui de_for_Business_1.pdf [Accessed 10 August 2008]

Husted, B. W., and Allen, D. B., 2001. Towards a Model of Corporate Social Strategy Formulation. Presented at the Social Issues in Management Division, Academy of Management, August 2001

Porter, M. E., and Kramer, M. R., 2006. Strategy and Society: The Link Between Competitive Advantage And Corporate Social Responsibility. Harvard Business Review, December 2006

Schermerhorn, J.R., 2004. Management, $8^{\text {th }}$ Edition. New Jersey, John Wiley and Sons Inc.

Waddock, S.A., and Graves, S. B., 1997. The Corporate Social Performance- Financial Performance Link. Strategic Management Journal, 18/4, 303-319.

Wall, E., 2008. Creating Value Through Corporate Social Responsibility Programs. Available from:

http://www.law.com/jsp/law/careercenter/lawArticleCareerCenter.jsp?id=1202423541991 [Accessed 14 August 2008]

Wood, D. J., and Jones, R. E., 1995. Stakeholder mismatching: A theoretical problem in empirical research in corporate social performance. International Journal of Organizational Analysis, 3/3, 229-267.

Zadek, S., 2004. The Path to Corporate Responsibility. Harvard Business Review Online. December 2004. Available from: http://organizacionysistemas.com/ARTICULOS/cr.pdf [Accessed 20 August 2009] 